\title{
Howland Award Presentation to Robert A. Good
}

\author{
PAUL G. QUIE \\ Department of Pediatrics, Division of Infectious Diseases, University of Minnesota Medical School, \\ Minneapolis, Minnesota 55455
}

A last minute illness prevented Lewis Thomas from traveling to California and presenting the John Howland award to Dr. Robert Good. This disappointing information reached us late last evening and President Sam Katz asked me to make the Howland Award presentation in Lewis Thomas' stead. I am deeply honored by this invitation to present the John Howland Award to Bob Good, my close colleague and dear friend of many, many years. I will read a communication from Lewis Thomas; but want first to express my own deep admiration and respect for Bob. I will outline in broad brush strokes my observation of his contribution to pediatrics.

When Lewis Thomas left the pediatric department at Minnesota for the position of Chairman of Pathology and then Medicine at New York University in 1954, Bob Good was named Dr. Thomas' successor as The American Legion Memorial Heart Research Professor of Pediatrics at the University of Minnesota. What glory Dr. Good brought to that professorship! Many of you remember the early 1950 s when the thymus was considered an organ which was permissible to irradiate, and lymphocytes were peripheral blood leukocytes faithfully counted and considered useful for diagnosing pertussis but little else.

Bob Good and colleagues in the American Legion laboratory at Minnesota revolutionized our concepts about the immune system and host defenses against infections during the next two decades. The vital role of the thymus was discovered. The two compartment system of the immune system established with brilliant experimental confirmation of thymus-influenced cellmediated immunity and bursa or bone marrow-derived humoral immunity. T cells, B cells, plasma cells, and germinal centers become part of our everyday language. Predictions of the possibilities of bone marrow transplantation and other cellular engineering were made and successfully applied with astonishing success. My powers of description are not able to convey the vigor, excitement and sheer joy of discovery that permeated our department of pediatrics during these Good years.

An even more precious legacy for us at Minnesota was the richness of participating with Bob Good as a clinical pediatrician caring for sick children. He has always cared so much. Bob's generosity is enormous. He gives with abandon to his patients, parents, students, and colleagues with his heart as well as his time and his mind. Kindness and generosity were coupled with tremendous energy, vitality, and competitiveness. Our colleagues could always tell when we had spent part of the day with Bob Good. We would be bubbling with ideas and eager to try them out. Bob's enthusiasm was powerfully contagious.

Presented at the American Pediatric Society meeting, Anaheim, CA, April 1987. Reprint requests Paul G. Quie, M.D., Department of Pediatrics, Division of Infectious Diseases, Medical School, Box 483 Mayo Memorial Building, 420 Delaware Street SE, Minneapolis, MN 55455.
Dr. Good was recruited to New York in 1974 where he directed the Sloan-Kettering Cancer Center for several years and teamed up again with his former Minnesota colleague, Lewis Thomas. The medical community continued to be advanced by Bob Good's genius, and new knowledge of cancer immunology greatly improved life for children with malignancy. You will hear more specific information about those accomplishments from Paul Kincade and Richard O'Reilly during the Howland Award Symposium following this presentation.

Dr. Good is back in the main stream of pediatrics now as Pediatrician-in-Chief at the All Children's Hospital in St. Petersburg, Florida and Professor of Pediatrics at the University of South Florida Medical School.

I would like now to present a letter prepared by Lewis Thomas.

April 27, 1987

I deeply regret that a last minute illness makes it impossible for me to come to Anaheim for the presentation of the Howland Award to Bob Good.

This would have been a high point in our 37 year close friendship, during which I have been a constant admirer of his remarkable talent, energy and integrity.

Let me say several things about Bob, long-distance:

$\mathrm{He}$ is the best clinical scientist I have ever encountered, more imaginative, probing, sharp-eyed, and open to new ideas than all his peers. He possesses an astounding memory, holding everything within easy reach, recalling every patient whose bedside he has graced, every paper he ever read, even (and this takes a capacious memory) the fine details of all the papers he has written himself.

His discoveries have been landmarks in cellular immunology, child development, the genetics of pediatric disease, the influence of nutrition on resistance and longevity, the mechanisms of tissue injury, the evolution of the immune system, and the technology of bone marrow transplantation. As a scientist, he has cast the widest of nets, and brought in a rich catch.

As a teacher, he ranks among the best in the trade, with harvest after harvest of bright young people who have been touched and inspired by his influence.

And as a man, he has acquired a host of warm friends, who are devoted to him and rely upon him. Always bursting with new ideas, which he gives away freely like presents, he brings excitement to even the most casual conversation.

Looking back over the roster of Howland Medalists, he now joins good company indeed. Please convey my congratulations to Bob, and my felicitations to the Society for the wisdom of their choice. Lewis Thomas, M.D.

Bob, it gives me great honor to present the John Howland Award to you on behalf of the American Pediatric Society. 